\title{
Comparative study of duration of action and cardiovascular effects of bronchodilator aerosols
}

\author{
B. J . FRE E D A N and G. B. H I L L \\ King's College Hospital, London S.E.5 and the General Register Office, Somerset House, London W.C.2
}

The durations of action and side effects of four different pressurized bronchodilator aerosols were compared. One of the preparations contained isoprenaline alone, which was given in a dose of $400 \mu \mathrm{g}$. The doses of the three other preparations were adjusted to yield nearly the same peak bronchodilator response as was obtained from $400 \mu \mathrm{g}$ isoprenaline. These doses differed from those yielded by a single discharge of the standard commercial product. The duration of action of orciprenaline was greater than those of the other preparations. There were no cardiovascular side effects from any of the four preparations. An attempt has been made to establish the principle that drugs whose primary action is similar should be given in equipotential doses when comparing duration of action and side effects.

In an earlier paper (Freedman, Meisner, and Hill, 1968) we compared the effectiveness of five commercially available bronchodilator aerosols. Three of these-Medihaler Iso Forte, MedihalerDuo, and Prenomiser Plus-contained different doses of isoprenaline; the other two aerosols contained analogues of isoprenaline-orciprenaline in Alupent and isoetharine in Bronchilator.

We showed that the maximum response to the preparations containing isoprenaline, as judged by the percentage increase in the forced expiratory volume in one second $\left(\mathrm{FEV}_{1.0}\right)$ over basal, was approximately linearly related to the logarithm of the dose of isoprenaline. Using this doseresponse line and assuming that the various

\section{T A B L E I}

BRONCHODILATOR AEROSOLS: ADJUSTMENT MADE TO COMMERCIALLY AVAILABLE PREPARATIONS TO OBTAIN EQUAL PEAK RESPONSE, AND THE RESULTING COM-

\begin{tabular}{|c|c|c|c|c|}
\hline & \multicolumn{4}{|c|}{ Treatment Code } \\
\hline & $\mathbf{A}$ & B & C & $\mathbf{D}$ \\
\hline $\begin{array}{l}\text { Adjustment factor } \\
\text { Resulting constituents } \\
(\mu \mathrm{g}):\end{array}$ & $1 \cdot 33$ & $2 \cdot 5$ & $1 \cdot 0$ & $2 \cdot 5$ \\
\hline $\begin{array}{l}\text { Isoprenaline sulphate } \\
\text { Isoetharine }\end{array}$ & 二 & $8 \overline{75}$ & 400 & 400 \\
\hline $\begin{array}{l}\text { Isoetnarine } \\
\text { Orciprenaline }\end{array}$ & $1,0 \overline{0}$ & $\frac{813}{79}$ & - & - \\
\hline $\begin{array}{l}\text { Phenylephrine } \\
\text { Thenyldiamine }\end{array}$ & 二 & $\begin{array}{r}175 \\
75\end{array}$ & 二 & 600 \\
\hline
\end{tabular}

Code, $\mathbf{A}=$ Alupent. $\mathbf{B}=$ Bronchilator. $\mathbf{C}=$ Medihaler Iso Forte. $\mathbf{D}=$ Medihaler-Duo. adjuvants contained in some of the preparations exerted negligible effect on this early peak response, we were able to estimate the doses required to give equal peak response.

In this way, and with the co-operation of the manufacturers, pressurized aerosols of Alupent (A), Bronchilator (B), and Medihaler-Duo (D) were prepared which we would expect to give a peak response equal to that of a single discharge of Medihaler Iso Forte (C). The composition of these modified aerosols, in the dosages given, is shown in Table I.

When comparing the duration of action and unwanted effects of drugs with an immediate action it is clearly desirable to give them in doses which give equal maximum benefit.

\section{METHOD}

The four preparations were given to 11 asthmatic patients in random order on separate days. The $\underset{\omega}{N}$ patients comprised seven male and four female out- $\bar{O}$ patients. Their ages ranged from 31 to 69 years, mean age 51 years. As the extent of the response depends,

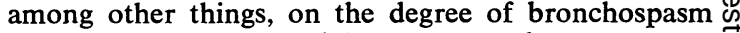
before treatment, especial care was taken to ensure that the basal $\mathrm{FEV}_{1.0}$ of each patient varied as little as possible. If necessary, tests were postponed to $\frac{\mathrm{O}}{\mathbb{D}}$

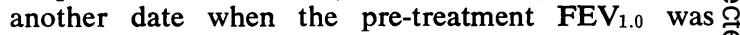
more appropriate.

The tests were begun at 10 a.m. In order to ensure $\sigma$ the absence of residual bronchodilator activity from 
drugs taken before the tests, patients abstained from bronchodilators during the preceding six hours, with one exception-a patient who could not manage to travel without taking orciprenaline, $10 \mathrm{mg}$ orally, four and a half hours before each test. Six patients regularly taking prednisolone maintained their usual dosage.

The following were measured before inhalation of the test aerosol: FEV $_{1.0}$ (Vitalograph dry spirometer), blood pressure and heart rate. These measurements were repeated at five-minute intervals until at least two consecutive values were obtained which differed by not more than $10 \%$. A pre-treatment electrocardiogram (ECG) tracing was made. After administration of the drug by inhalation the $F V_{1.0}$ was measured at $5,15,30,60,90,120$, and 180 minutes ; the heart rate and blood pressure were recorded at approximately two-minute intervals over the first quarter of an hour. From the moment of inhalation the ECG, lead II, was recorded continuously for 10 minutes.

\section{RESULTS}

The basal FEVs of the 11 patients on the four treatments are shown in Table IIa together with the expected values based on sex, age, and height. It is seen that, although there is considerable variation among the patients, the variation within

\section{T A B L E I I a}

PRE-TREATMENT FEV AND COMPARISON WITH EXPECTED VALUE

\begin{tabular}{|c|c|c|c|c|c|c|c|}
\hline \multirow{2}{*}{ Patients } & \multicolumn{4}{|c|}{ Pre-treatment FEV (litres) } & \multirow{2}{*}{ Mean } & \multirow{2}{*}{$\underset{\text { ted }}{\text { Expec- }}$} & \multirow{2}{*}{$\begin{array}{c}\text { Mean/ } \\
\text { Expec- } \\
\text { ted }\end{array}$} \\
\hline & $\mathbf{A}$ & B & C & D & & & \\
\hline $\begin{array}{r}1 \\
2 \\
3 \\
4 \\
5 \\
6 \\
7 \\
8 \\
9 \\
10 \\
11\end{array}$ & $\begin{array}{l}1.45 \\
2.16 \\
2.60 \\
2.98 \\
0.77 \\
0.52 \\
1.70 \\
1.39 \\
1.62 \\
1.07 \\
1.62\end{array}$ & $\begin{array}{l}1.45 \\
1.74 \\
2.53 \\
3.03 \\
0.78 \\
0.58 \\
1 \cdot 57 \\
1 \cdot 26 \\
1.54 \\
1.07 \\
1.77\end{array}$ & $\begin{array}{l}1.52 \\
2.24 \\
2.50 \\
2.90 \\
0.68 \\
0.53 \\
1.29 \\
1.42 \\
1.53 \\
1.27 \\
1.63\end{array}$ & $\begin{array}{l}1.56 \\
2.26 \\
2 \cdot 56 \\
3.47 \\
0.81 \\
0.46 \\
1 \cdot 25 \\
1 \cdot 12 \\
1 \cdot 55 \\
1 \cdot 07 \\
1 \cdot 80\end{array}$ & $\begin{array}{l}1 \cdot 50 \\
2 \cdot 10 \\
2 \cdot 55 \\
3 \cdot 10 \\
0 \cdot 76 \\
0 \cdot 52 \\
1 \cdot 45 \\
1 \cdot 30 \\
1 \cdot 56 \\
1 \cdot 12 \\
1 \cdot 71\end{array}$ & $\begin{array}{l}2.75 \\
3.62 \\
3.40 \\
3.49 \\
1.80 \\
2 \cdot 50 \\
2.00 \\
3.43 \\
2.75 \\
2 \cdot 10 \\
2.40\end{array}$ & $\begin{array}{l}0.55 \\
0.58 \\
0.75 \\
0.89 \\
0.42 \\
0.21 \\
0.73 \\
0.38 \\
0.57 \\
0.53 \\
0.71\end{array}$ \\
\hline Mean & $1 \cdot 63$ & 1.57 & 1.59 & 1.63 & & & \\
\hline
\end{tabular}

$\mathbf{A}=$ Alupent. $\mathbf{B}=$ Bronchilator. $\mathbf{C}=$ Medihaler Iso Forte. $\mathbf{D}=$ Medihaler-Duo.

T A B L E I I b

ANALYSIS OF VARIANCE OF PRE-TREATMENT FEV

\begin{tabular}{|c|c|c|c|c|c|}
\hline $\begin{array}{l}\text { Source of } \\
\text { Variation }\end{array}$ & $\begin{array}{l}\text { Sum of } \\
\text { Squares }\end{array}$ & $\begin{array}{c}\text { Degrees of } \\
\text { Freedom }\end{array}$ & $\begin{array}{l}\text { Mean } \\
\text { Square }\end{array}$ & F Ratio & $\begin{array}{c}\text { Signifi- } \\
\text { cance }\end{array}$ \\
\hline $\begin{array}{l}\text { Patients } \\
\text { Treatments } \\
\text { Residual } \\
\text { Total }\end{array}$ & $\begin{array}{r}22.4657 \\
0.0226 \\
0.6430 \\
23.1313\end{array}$ & $\begin{array}{r}10 \\
3 \\
30 \\
43\end{array}$ & $\begin{array}{l}2.2466 \\
0.0075 \\
0.0214\end{array}$ & $\begin{array}{r}104.82 \\
0.35\end{array}$ & $\begin{array}{c}\mathbf{P}<0.001 \\
\text { NS }\end{array}$ \\
\hline
\end{tabular}

patients is negligible. This is confirmed by the analysis of variance in Table IIb.

Figure 1 shows the mean response to the four drugs over the three hours following inhalation. The responses averaged are the absolute increases in $\mathrm{FEV}_{1.0}$ over the basal values. There is no consensus of opinion in the literature as to the best statistics to use in these circumstances. If the

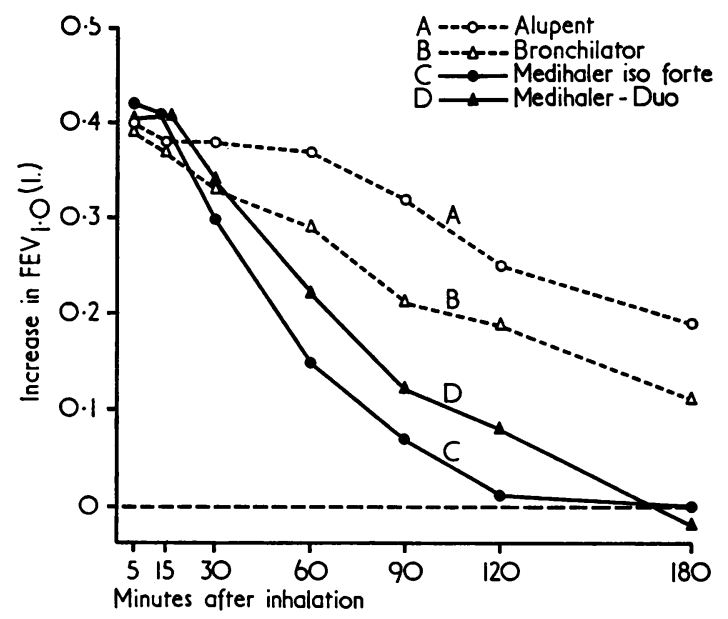

FIG. 1. Mean absolute changes in $F E V_{1.0}$ (litres) in 11 patients following inhalation of bronchodilator aerosols. The doses were adjusted (Table I) to yield almost identical peak values and, with the exception of $C$, were not those discharged from commercially available preparations.

$\mathrm{FEV}_{1.0}$ at time $\mathrm{t}$ minutes after inhalation is $x_{t}, t=0,5,15,30 \ldots$ then three possible measures of the response at time $t$ are:

(1) $x_{t}-x_{0}$ the absolute increase

(2) $100\left(x_{t}-x_{0}\right) / x_{0}$ the percentage increase

(3) $\log x_{t}-\log x_{0} \quad$ the logarithmic increase.

There are clinical and statistical arguments both for and against all these measures, but in this case all gave the same qualitative result and results are quoted only for the absolute increase.

The visual impression from Fig. 1 is that the adjustment of dose to achieve equal peak responses has been successful and the difference in duration of action of the four treatments then becomes obvious. It is not possible to draw statistical conclusions from these mean responses (Oldham, 1968). For this purpose it is necessary to calculate suitable summary statistics from the 
response of each patient to each drug. The statistics which are of interest are: $\delta \max =\max \left(x_{t}-x_{0}\right)$, the peak response

and $\triangle$, the integral of $\left(x_{t}-x_{0}\right)$ over the first three hours, assuming linear change between data points, i.e., the area under the response curve.

If $\delta \max$ is on average the same for each treatment then differences between treatment averages of $\triangle$ reflect differences in duration of action.

Table IIIa gives the values of $\delta$ max for the 11 patients on each of the four treatments, and the analysis of variance in Table IIIb confirms that

T A B L E I I I a

MAXIMUM INCREASES IN FEV (LITRES) OVER PRETREATMENT VALUES

\begin{tabular}{c|c|c|c|c|c}
\hline \multirow{2}{*}{ Patients } & \multicolumn{5}{|c}{ Value of $\delta$ Max on Treatment } \\
\cline { 2 - 6 } & A & B & C & D & Mean \\
\hline 1 & 0.31 & 0.30 & 0.37 & 0.28 & 0.32 \\
2 & 0.50 & 0.79 & 0.65 & 0.56 & 0.63 \\
3 & 0.41 & 0.47 & 0.42 & 0.48 & 0.45 \\
4 & 0.65 & 0.65 & 0.81 & 0.41 & 0.63 \\
5 & 0.41 & 0.33 & 0.41 & 0.38 & 0.38 \\
6 & 0.31 & 0.31 & 0.27 & 0.34 & 0.31 \\
7 & 0.23 & 0.23 & 0.45 & 0.24 & 0.29 \\
8 & 0.29 & 0.22 & 0.33 & 0.51 & 0.34 \\
9 & 0.26 & 0.22 & 0.19 & 0.26 & 0.23 \\
10 & 0.66 & 0.60 & 0.60 & 0.67 & 0.63 \\
11 & 0.70 & 0.32 & 0.54 & 0.66 & 0.56 \\
Mean & 0.43 & 0.40 & 0.46 & 0.44 & 0.43 \\
& & & & & \\
\hline
\end{tabular}

$\mathbf{A}=$ Alupent. $\mathbf{B}=$ Bronchilator. $\mathbf{C}=$ Medihaler Iso Forte. $\mathbf{D}=$ Medihaler-Duo.

T A B L E I I I b

ANALYSIS OF VARIANCE OF MAXIMUM INCREMENTS IN

\begin{tabular}{|c|c|c|c|c|c|}
\hline \multicolumn{6}{|c|}{ FEV } \\
\hline $\begin{array}{l}\text { Source of } \\
\text { Variation }\end{array}$ & $\begin{array}{l}\text { Sum of } \\
\text { Squares }\end{array}$ & $\begin{array}{l}\text { Degrees of } \\
\text { Freedom }\end{array}$ & $\begin{array}{c}\text { Mean } \\
\text { Square }\end{array}$ & F Ratio & $\begin{array}{l}\text { Signifi- } \\
\text { cance }\end{array}$ \\
\hline $\begin{array}{l}\text { Patients } \\
\text { Treatments } \\
\text { Residual } \\
\text { Total }\end{array}$ & $\begin{array}{l}0.9328 \\
0.0166 \\
0.3041 \\
1.2535\end{array}$ & $\begin{array}{r}10 \\
3 \\
30\end{array}$ & $\begin{array}{l}0.09328 \\
0.00553 \\
0.01014\end{array}$ & $\begin{array}{l}9 \cdot 20 \\
0.54\end{array}$ & $\begin{array}{c}\mathrm{P}<0.001 \\
\text { NS }\end{array}$ \\
\hline
\end{tabular}

the difference between the treatments is not significant. Table IVa gives the values of $\Delta$ in like manner and the analysis of variance is shown in Table IVb. In this case the difference between treatments is significant and the rank order of the treatments judged by the mean is the same as that obtained visually from Figure 1 . The individual means are compared and tested for significance in Table V. The method used is based on the studentized range statistic (Newman-Keuls test, vide Snedecor and Cochran, 1967). It is seen
T A B L E IV a

INCREMENT IN FEV INTEGRATED OVER FIRST THREP HOURS

\begin{tabular}{|c|c|c|c|c|c|}
\hline \multirow{2}{*}{ Patients } & \multicolumn{5}{|c|}{ Value of $\Delta$ on Treatment } \\
\hline & $\mathbf{A}$ & $\mathbf{B}$ & $\mathbf{C}$ & $\mathbf{D}$ & Mean \\
\hline $\begin{array}{c}1 \\
2 \\
3 \\
4 \\
5 \\
6 \\
7 \\
8 \\
9 \\
10 \\
11 \\
\text { Mean }\end{array}$ & $\begin{array}{r}13 \cdot 56 \\
27 \cdot 53 \\
23 \cdot 12 \\
37 \cdot 04 \\
27 \cdot 79 \\
17 \cdot 90 \\
7 \cdot 85 \\
18 \cdot 47 \\
9 \cdot 20 \\
40 \cdot 97 \\
18 \cdot 78 \\
21 \cdot 56\end{array}$ & $\begin{array}{r}0 \cdot 30 \\
53 \cdot 51 \\
23 \cdot 07 \\
38 \cdot 32 \\
9 \cdot 27 \\
5 \cdot 48 \\
10 \cdot 36 \\
8 \cdot 17 \\
3 \cdot 02 \\
23 \cdot 52 \\
7 \cdot 96 \\
16 \cdot 63\end{array}$ & $\begin{array}{r}4 \cdot 19 \\
20.67 \\
12.64 \\
21.45 \\
-2.32 \\
1.27 \\
9.92 \\
12.60 \\
-5.27 \\
-0.75 \\
23.67 \\
8.92\end{array}$ & $\begin{array}{r}4.01 \\
19 \cdot 27 \\
14.97 \\
12.53 \\
4.78 \\
4.89 \\
-3.11 \\
27.24 \\
-2.42 \\
16.40 \\
28.26 \\
11.53\end{array}$ & $\begin{array}{r}5 \cdot 52 \\
30 \cdot 25 \\
18 \cdot 45 \\
27 \cdot 34 \\
8 \cdot 63 \\
7 \cdot 39 \\
6 \cdot 26 \\
16 \cdot 62 \\
1 \cdot 13 \\
20 \cdot 04 \\
19 \cdot 67 \\
14 \cdot 66\end{array}$ \\
\hline
\end{tabular}

$\mathrm{A}=$ Alupent. $\mathbf{B}=$ Bronchilator. $\mathbf{C}=$ Medihaler Iso Forte. $\mathbf{D} \overline{\mathrm{D}}$

T A B L E I V b

ANALYSIS OF INTEGRATED INCREMENT IN FEV OVES FIRST THREE HOURS

\begin{tabular}{|c|c|c|c|c|c|}
\hline $\begin{array}{c}\text { Source } \\
\text { of } \\
\text { Variation }\end{array}$ & $\begin{array}{l}\text { Sum of } \\
\text { Squares }\end{array}$ & $\begin{array}{c}\text { Degrees } \\
\text { of Free- } \\
\text { dom }\end{array}$ & $\begin{array}{c}\text { Mean } \\
\text { Square }\end{array}$ & $\underset{\text { Ratio }}{\mathbf{F}}$ & $\begin{array}{l}\text { Signifi- } \\
\text { cance }\end{array}$ \\
\hline $\begin{array}{l}\text { Patients } \\
\text { Treatments } \\
\text { Residual } \\
\text { Total }\end{array}$ & $\begin{array}{l}3,609 \cdot 0963 \\
1,038 \cdot 1137 \\
2,439 \cdot 6518 \\
7,086 \cdot 8618\end{array}$ & $\begin{array}{r}10 \\
3 \\
30 \\
43\end{array}$ & $\begin{array}{r}360 \cdot 9096 \\
346.0379 \\
81 \cdot 3217\end{array}$ & $\begin{array}{l}4 \cdot 44 \\
4 \cdot 26\end{array}$ & $\begin{array}{l}\mathrm{P}<0.001 \\
0.01<\mathrm{P}<0\end{array}$ \\
\hline
\end{tabular}

T A B L E V

DIFFERENCES BETWEEN TREATMENT MEANS OF INT GRATED INCREMENT FEV (NEWMAN-KEULS TEST PROCEDURE)

\begin{tabular}{|c|c|c|c|}
\hline Treatment & D & $\mathbf{B}$ & A \\
\hline $\begin{array}{r}\text { Minus } \underset{\mathbf{D}}{\mathbf{D}} \\
\mathbf{B}\end{array}$ & $2 \cdot 61$ (NS) & $\begin{array}{l}7 \cdot 71 \text { (NS) } \\
5 \cdot 10 \text { (NS) }\end{array}$ & $\begin{array}{l}12.64^{1} \\
10.03^{1} \\
4.93 \text { (NS) }\end{array}$ \\
\hline
\end{tabular}

${ }^{1}$ Significant at $5 \%$ level. NS not significant at $5 \%$ level. $\mathbf{A}=$ Alupent. $\mathbf{B}=$ Bronchilator. $\mathbf{C}=$ Medihaler Iso Forte. $\mathbf{D}$ Medihaler-Duo.

\section{T A B L E V I}

CARDIOVASCULAR CHANGES OVER THE FIRST

\begin{tabular}{|c|c|c|c|c|c|}
\hline \multirow{2}{*}{ Variable } & \multicolumn{4}{|c|}{ Mean Value for Treatment } & \multirow{2}{*}{$\begin{array}{c}\text { Variange } \\
\text { RatiQ } \\
\text { F } \frac{3}{30} \text { 을. }\end{array}$} \\
\hline & $\mathbf{A}$ & B & C & $\mathbf{D}$ & \\
\hline $\begin{array}{l}\text { Heart rate }(\mathrm{b} / \mathrm{min}) \\
\text { Basal } \\
\delta \mathrm{Max}\end{array}$ & $\begin{array}{r}79 \cdot 4 \\
1 \cdot 7 \\
-25 \cdot 3\end{array}$ & $\begin{array}{r}77 \cdot 1 \\
3 \cdot 1 \\
3 \cdot 6\end{array}$ & $\begin{array}{r}78 \cdot 1 \\
4 \cdot 7 \\
16 \cdot 1\end{array}$ & $\begin{array}{r}75 \cdot 5 \\
4.9 \\
13.4\end{array}$ & $\begin{array}{l}0.68 \\
0.57 \mathrm{~N} \\
1.200\end{array}$ \\
\hline $\begin{array}{c}\text { Systolic BP }(\mathrm{mmHg}) \\
\text { Basal } \\
\delta \text { Max } \\
\triangle \\
\text { Diastolic BP }(\mathrm{mm}\end{array}$ & $\begin{array}{r}123 \cdot 5 \\
3 \cdot 4 \\
6 \cdot 3\end{array}$ & $\begin{array}{r}122 \cdot 8 \\
5 \cdot 5 \\
14 \cdot 0\end{array}$ & $\begin{array}{r}122 \cdot 7 \\
6 \cdot 9 \\
49 \cdot 5\end{array}$ & $\begin{array}{r}124 \cdot 4 \\
8 \cdot 0 \\
56 \cdot 4\end{array}$ & 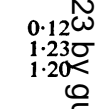 \\
\hline $\begin{array}{c}\text { Hg) } \\
\text { Basal } \\
\delta \text { Max } \\
\triangle \\
\text { Pulse pressure (mm } \\
\text { Hg) }\end{array}$ & $\begin{array}{r}78 \cdot 8 \\
2 \cdot 3 \\
3 \cdot 9\end{array}$ & $\begin{array}{r}79 \cdot 1 \\
5 \cdot 5 \\
18 \cdot 3\end{array}$ & $\begin{array}{r}78 \cdot 5 \\
1 \cdot 3 \\
-16 \cdot 2\end{array}$ & $\begin{array}{r}76 \cdot 7 \\
2 \cdot 9 \\
-9 \cdot 1\end{array}$ & $\begin{array}{l}0.49 \frac{\mathrm{C}}{\mathrm{C}} \\
1.97 \frac{\mathrm{T}}{\mathrm{O}} \\
1.022^{\circ}\end{array}$ \\
\hline $\begin{array}{c}\text { Basal } \\
\mathbf{8 M a x} \\
\triangle\end{array}$ & $\begin{array}{r}44 \cdot 6 \\
3 \cdot 7 \\
3 \cdot 2\end{array}$ & $\begin{array}{r}43 \cdot 7 \\
4 \cdot 1 \\
-4 \cdot 2\end{array}$ & $\begin{array}{r}44 \cdot 3 \\
7 \cdot 7 \\
65 \cdot 8\end{array}$ & $\begin{array}{r}47 \cdot 6 \\
9 \cdot 2 \\
65 \cdot 5\end{array}$ & $\begin{array}{l}1 \cdot 39 \frac{\mathrm{D}}{1} \\
1 \cdot 89 \frac{\mathrm{R}}{2 \cdot 38} \\
\text { (ृ) }\end{array}$ \\
\hline
\end{tabular}

10.05 $<\mathrm{P}<0.10$. $\mathrm{A}=$ Alupent. $\mathrm{B}=$ Bronchilator. $\mathrm{C}=$ Medihater Iso Forte. $\mathrm{D}=$ Medihaler-Duo. 
that $\mathrm{A}$ differs significantly from $\mathrm{D}$ and $\mathrm{C}$, but the other differences are not significant at the $5 \%$ level.

The differences in the cardiovascular effects of the drugs are less (Table VI, Fig. 2). The homogeneity of the basal values of heart rate and systolic and diastolic blood pressure mirrors that of the $F E V_{1 \cdot 0}$, and is confirmed by the $F$ ratios summarizing analyses of variance as in previous tables. As in the case of FEV1.0, two statistics were calculated for each variable: $\delta \max$, the maximum increase over the basal value, and $\Delta$, the integrated increment over the first 15 minutes. The average changes after the preparations containing isoprenaline are larger than after orciprenaline or isoetharine, but the $F$ ratios are not significant, the minor changes in heart rate and blood pressure are clinically unimportant, and perhaps scarcely merit an elaborate statistical analysis. The ECGs merely reflected changes in heart rate. In no instance did the complexes vary from the pre-treatment pattern.
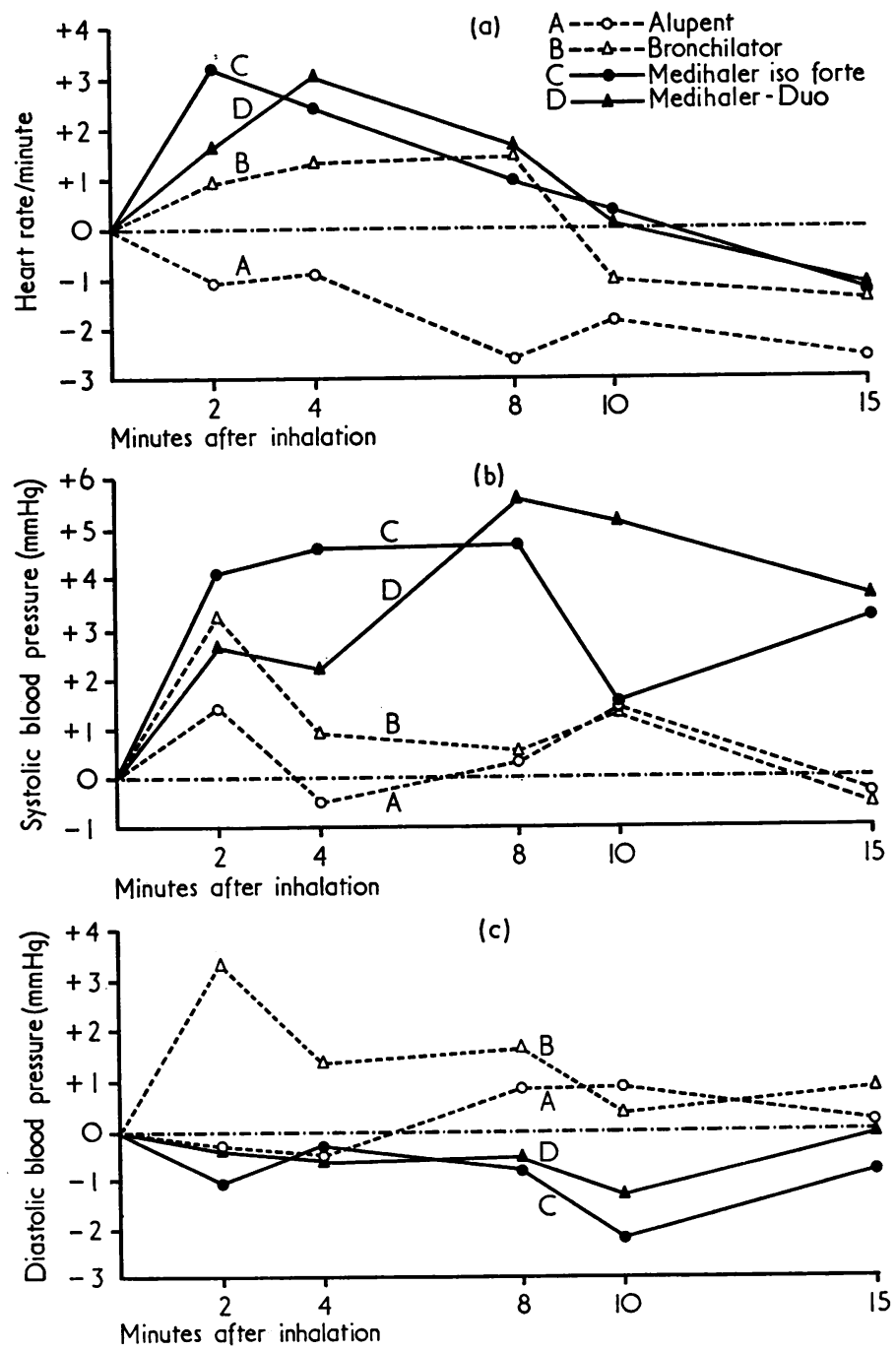

FIG. 2. Mean changes in (a) heart rate, (b) systolic blood pressure. and (c) diastolic blood pressure. 


\section{DISCUSSION}

The work described in this paper is an extension of our earlier work on a comparison of the actions of different bronchodilators (Freedman et al., 1968). The availability of 20 different makes of pressurized bronchodilator aerosol, all differing in composition or dosage, presents the clinician with an embarrassment of choice. Four of the five preparations used in the comparative trial were used in the present study. The pharmacology of the component drugs (Table I) will be briefly recapitulated. Isoprenaline stimulates all $\beta$-adrenergic receptors. Isoetharine and orciprenaline stimulate predominantly $\beta_{2}$-receptors, with some stimulation of $\beta_{1}$-receptors. The action of orciprenaline is claimed to be more persistent than that of isoprenaline. Phenylephrine stimullates $\alpha$-adrenergic receptors. Its vasoconstrictor action is believed to delay absorption and maintain the action of topically applied $\beta$-stimulators, and to prevent the ventilation-perfusion imbalance that sometimes causes a fall in arterial oxygen saturation after administration of stimulators (Hume, 1970). Thenyldiamine is an antihistamine. Its effect in naturally occurring asthma is doubtful.

In the previous trial the doses administered were those contained in a single discharge from a pressurized container. The results showed that the level of the peak response was dependent, among other things, on dosage. We concluded that, in comparative experiments of this type, differences in duration of effect were likewise dosedependent, and that, if one wished to compare decay rates of different drugs having similar pharmacological actions, the doses administered $\overrightarrow{\vec{F}^{\circ}}$ must be standardized. The same was true whencomparing side-effects and toxic actions. We등 think that the failure to give equipotential bron- $\frac{\overline{\bar{c}}}{\overline{\mathrm{n}}}$ chodilator doses has impaired the validity of $a \widehat{\Phi}$ number of previously published comparative trials.

From results obtained in our earlier work on $\vec{\circ}$ relative bronchodilator potencies, we succeeded $\overrightarrow{-}$ in the present trial in administering doses that $\bar{\sigma}_{\sigma}$ yielded nearly identical peak responses. Our $\overrightarrow{\overrightarrow{2}}$ results show that, when inhaled in equipotential peak bronchodilator doses, the action of orci- $\widetilde{N}$ prenaline is more prolonged than that of the three. other preparations, whose durations of action doo not differ significantly at the $5 \%$ level. In the doses given, changes in heart rate and bloodpressure were trivial, not clinically important, and there were no ECG changes with any of the preparations.

Our thanks are due to Messrs. Riker Laboratories, $\vec{\oplus}$ Boehringer-Ingelheim, and Winthrop Laboratories for.their co-operation in preparing special concentrationsof pressurized aerosol, and to the first two firms for? financial support towards technical assistance.

\section{REFERENCES}

Freedman, B. J., Meisner, P., and Hill, G. B. (1968). A comparison of the actions of different bronchodilators in asthma. Thorax, 23, 590.

Hume, K. M. (1970). Blood-gas tensions and aerosols. Brit. med. J., 1, 173.

Oldham, P. D. (1968). Measurement in Medicine, p. 190 et seq. English Universities Press, London.

Snedecor, G. W., and Cochran, W. G. (1967). Statistical Methods, 6th ed., pp. 273-275. Iowa State Universityx Press, Ames, Iowa. 